$82-211.6 .09$

М. О. Дудніков

\title{
ОСНОВНІ ЛІТЕРАТУРОЗНАВЧІ КОНЦЕПЦІЇ ЖАНРУ «РОМАН» У КОНТЕКСТІ ГЕНЕЗИ
}

Дудніков М. О. Основні літературознавчі концепції жанру «роман» у контексті генези.

У статті пропонуються теоретичні та історико-літературні концепції жанрових ознак роману в контексті їх розвитку, починаючи з літератури античності до першої половини XX століття. Значну увагу приділено теоретичним працям, які вважають фундаментальними в галузі поетики та типології романного жанру.

Ключові слова: роман, жанр, епос, грецький роман, лицарський роман, російський роман.

Дудников Н. А. Основные литературоведческие концепции жанра «роман» в контексте генезиса.

В статье предлагаются теоретические и историко-литературные концепции жанровых признаков романа в контексте их развития, начиная с литературы античности о первой половины $\mathrm{XX}$ столетия. Большое внимание уделяется теоретическим трудам, которые являются фундаментальными в области поэтики и типологии романного жанра.

Ключевые слова: роман, жанр, эпос, греческий роман, рыцарский роман, русский роман.

Dudnikov Nick. Basic concepts literary genre "romance"in the context of origin.

The paper proposes a theoretical and literary history of the concept of genre features of the novel in the context of their development, starting with the ancient literature of the first half of the twentieth century. Much attention is paid to the theoretical writings, which are fundamental to the poetics and typology novelistic genre.

Key words: novel, genre, epics, the greek novel, romance, russian novel.

У літературознавстві немає усталеної думки щодо виникнення жанру роману: на думку О. Михайлова, він з'явився у Європі на початку Нового часу, а такі атрибутивні поширювачі, як «грецький», «середньовічний» до роману можна віднести лише умовно [17], В. Кожинов вбачає його витоки в крутійських оповіданнях [14]. Є намагання зарахувати до роману його ранні форми періоду античності та середньовіччя.

Як жанровий термін поняття «роман» вперше використав у XVI ст. англійський дослідник літератури Джордж Патенхем у праці «Мистецтво англійської поезії» (1589р.). Перше теоретичне дослідження про роман написав у 1670 р. французький монах П'єр Даніель Гює. У своїй праці «Трактат про походження роману» він стає на захист роману, який класицистська критика зарахувала до низьких літературних жанрів, 
призначених для простолюду. Деталізуючи формально-змістовні особливості героїчної форми «romance», теоретик акцентує увагу на іiі інваріанті, який стосується дидактичної спрямованості (перемога добра та покарання зла), любовний тематичний ареал i строкату екзотику вигаданої історії, побудованої на реальних подіях у минулому. Висловлюючи солідарність із загальною спрямованістю французької культури XVII ст., що визначалася культом жінки, літературознавець знаходить ключові естетичні характеристики галантно-героїчної модифікації роману, послуговується термінами «вишуканість» (англ. «decorum» від фр. «bienseance» [Huet]) i «правдивість» (англ. «truth to the nature» від фр. «vraisemblance» [Huet]). Англійський переклад C. Л’юїса був надрукований під назвою «Історія романів у 1715 році») («Тhе History of Romances in 1715») і представлений у збірці під редагуванням I. Уїльямса «Роман і роменс» («Novel and Romance» [35].

Роман - це жанр, що передусім відображає багатогранне, складне життя, яке неможливо утримати в межах певних норм, а тому він уникає нормативних меж літературних жанрів, уже тривалий час розвивається як абсолютно вільна форма, зазнає при цьому нових модифікацій. Ось чому проблеми історії та теорії роману набули особливої наукової актуальності. Різні аспекти поетики та типології цього жанру розроблені у працях В. Жирмунського, М. Кузнєцова, Г. Поспєлова, Є. Мелетинського, М. Андрєєва, Д. Затонського, Н. Тамарченко, М. Соколянського, В. Недзвецького, А. Есалнек, М. Римаря та ін. Особливе місце серед цілої плеяди літературознавців належить М. Бахтіну, який збагатив науку поняттями про монологічну та поліфонічну структуру роману, підкреслив особливість цього жанру, що характеризується його «неготовністю», його «становленням». Відображаючи дійсність, яка стрімко змінюється, роман так само стрімко еволюціонував, випереджаючи інші жанри. Аби дати відповідь щодо здобутків попередніх поколінь романістів у галузі поетики жанру, які визначили домінувальну роль роману в сучасному розвитку літератури, вважаємо за доречне простежити розвиток теоретичних суджень про роман, починаючи з часів пізньої античності до сучасності.

Літературна критика вважає, що передумови виникнення роману слід шукати в IV ст. н. е., пов'язує його 3 появою таких творів грецького історика Ксенофонта, як «Анабазис» і «Виховання Каїра». Сама назва «роман» з'явилася, як ми зазначили вище, набагато пізніше, у середні віки. Давні греки називали свої романи оповідями (logoi), а то 
й просто книгами - bibloi. Давньогрецькі романи (рідше «античні романи») раннього часу не збереглися. Повністю до нас дійшли романи, написані в II-IV ст. н .е. («Ефіопіка» Геліодора, «Левкіппа і Клітофонт» Ахілла Татія, «Дафніс і Хлоя» Лонга та деякі інші).

У 1920-х р. з'явилася інформація доступна широкому загалу про античні риторики, авторство яких, на жаль, втрачено. У них роман визначався як особливий рід оповідання: «Цей рід оповідання повинен містити в собі: веселий тон оповіді, несхожі характери, серйозність та легковажність, надію, острах, підозру, прикидання, співчуття, різномастість подій, зміну долі, несподівану втечу, раптову радість, приємне завершення подій» [2, с. 15]. Як бачимо, основними ознаками роману невідомий автор риторики вважає: зосередженість на психологічному стані персонажів та на важливій ролі сюжетної побудови - розмаїтті подій. Подібний тип оповідання греки номінували то драмою, то епосом. Дослідник Е. Роде, називаючи грецький роман «історичною драмою», поєднував таким чином два жанри давньогрецької літератури.

Зовсім іншу лінію розвитку античного роману являють собою латиномовні твори. Насамперед це роман Петронія «Сатирикон», написаний у формі меніппової сатири. Її вплив, на думку М. Бахтіна, відчувається і в іншому творі пізньої античності «Золотому віслюку» Апулея.

Вивчення давньогрецького роману починається 3 труднощів термінологічного порядку. Сам термін «роман» має не грецьке, а середньовічне походження і до грецького роману застосовується, згідно 3 позицією деяких дослідників, у певній мірі умовно [7, с. 243]. В. Шкловський, зокрема, писав: використовувати термін «роман» стосовно оповідань грецької літератури треба обережно, «щоб разом 3 терміном не перенести пізні уявлення на ранні явища» [29, с. 140]. Але ж термін «роман» уже багато століть вживається відповідно до групи творів античної літератури, які, безумовно, демонструють жанрову схожість.

Важливим етапом у розвитку європейського роману був лицарський роман. Його вивчення є складовою частиною загальної теорії та історії роману. В оповіданнях кращих авторів лицарських романів - Крет'єна де Труа, Гартмана фон Ауе, Вольфрама фон Ешенбаха, а також їх попередників та послідовників - створено типові образи лицарів і дам, які втілювали ідеали лицарського суспільства.

Установлено, що лицарський роман має в історії розвитку жанру певне значення: знаменує початок усвідомленого художнього вимислу 
в літературі та індивідуальної творчості. У його поетиці широко використовувалися оповідальні кліше: вихідне положення, зав'язка, розвиток сюжету, виражене в різноманітних подвигах, стереотипних зустрічах з ворогами, але ці кліше набагато більше індивідуалізовані порівняно з героїчним епосом. Загалом лицарський роман знаменує початок нового етапу розвитку європейського роману.

Безперечно, один із найважливіших етапів в історії роману пов'язаний 3 епохою Просвітництва, періодом становлення роману Нового часу. До цього ж періоду належать і перші систематичні спроби осмислення місця та ролі жанру роману в літературному процесі, а також самої його жанрової сутності. У цьому плані особливо цікавими $є$ тведження романістів XVII-XVIII ст., якими вони супроводжували свої твори. У зв'язку з цим слід згадати дві передмови: Г. Філдинга до його роману «Історія Тома Джонса, знайди» і X. Віланда до роману «Історія Агатона», де автори пояснюють нові підходи до зображення романного героя і всього того, що було, на їх думку, важливим і суттєвим у творах, запропонованих читачеві. Досвід романістів, передусім Філдінга та Віланда, є важливим, оскільки: по-перше, це твердження самих авторів романів, висловлені тоді, «коли новаторська сутність роману сприймалася надзвичайно гостро й свіжо» [13, с. 12]; по-друге, говорячи про історію жанру, М. Бахтін оцінює твердження цих письменників як етапні в розумінні сутності жанру.

Про Г. Філдинга, відомого англійського просвітителя XVIII ст., прийнято говорити як про творця нового реалістичного типу роману. Значне досягнення Г. Філдинга - його роман «Історія Тома Джонса, знайди», перейнятий просвітницькою життєрадісністю та гармонійним сприйняттям життя й людини. Характер центрального героя втілює риси тієї особистості, яка приходить у літературу Нового часу й зумовлена ним. Саме про це говорить Г. Філдинг у своій передмові «Вступ до роману, або Список страв на банкеті», написаній у 1749 році. Він метафорично порівнює письменника з господарем харчевні, який заготував провізію на різні смаки своїх відвідувачів, тому що вони «обов'язково хочуть отримати щось на свій смак», підкреслює, що «заготована провізія є не що інше, як людська природа» [26, с. 30] і що читач не може не знати, наскільки різноманітна ця людська природа, а тому треба докласти чимало зусиль, перш ніж «письменник вичерпає таку широку тему».

Для Г. Філдинга головний інтерес роману - людина, її розвиток: «Ми пропонуємо людську природу у простому й природному вигляді, 
у якому вона трапляється в селі, а потім начинимо й приправимо іiі всілякими тонкими французькими та італійськими спеціями вдавання та пороків, які виготовляються при дворах і в містах» [26, с. 31].

Основне в романі - людина та ii взаємостосунки зі світом i формування іiі особистості обставинами власного життя. Таке розуміння колізії роману ми знаходимо й у М. Бахтіна. Ця думка Г. Філдинга в різних варіаціях буде неодноразово повторена Бахтіним майже в усіх його твердженнях про роман.

Підкреслюючи значення висловлювань про роман, М. Бахтін у статті «Епос і роман» зауважує: «Для всіх цих висловлювань, що відображають становлення роману в одному із суттєвих етапів («Том Джонс», «Агатон», «Вільгельм Мейстер») характерні такі вимоги: 1) роман не повинен бути «поетичним» у тому смислі, у якому поетичними є інші жанри художньої літератури; 2) герой роману не повинен бути «героїчним» ні в епічному, ні в трагічному смислі цього слова: він має об’єднувати як позитивні, так і негативні риси, як низькі, так і високі, як смішні, так і серйозні; 3) герой повинен бути показаний не як готовий і незмінний, а як такий, що проходить процес становлення, змін, виховання життям; 4) роман повинен стати для сучасного світу тим, чим епопея була для давнього світу» [3, с. 454].

Значний внесок у розробку теорії роману та вивчення його історії внесла німецька класична естетика. Особливу увагу слід звернути на роботи Г. Гегеля, а також судження про роман двох видатних письменників Німеччини XVIII ст. - I. Гете і В. Шиллера.

I. Гете назвав роман «суб'єктивною епопеєю», у центрі якої стоїть особистість, здатна жити тільки в атмосфері високого духовного напруження. На відміну від I. Гете, Г. Гегель визначив роман як «сучасну епопею громадянського життя» і побачив у ньому об'єктивний жанр. Подібна ситуація є показовою для романного жанру, у якому присутня одночасно й об’єктивна сторона - життя з його труднощами та суперечностями, і сам оповідач, що висловлює суб'єктивне начало.

Німецький філософ побудував свою теорію роману, яка впродовж кількох століть слугувала своєрідним орієнтиром для всіх тих, хто звертався до вивчення роману або побудови його теорії. Г. Гегель вважав, що змістом епосу є цілісність світу, де відбувається індивідуальна дія, тому в епосі трапляється розмаїття предметів, які складають цей світ. У епосі є місце для «цілісності світу», для всього, що «тільки можна зарахувати до поезії людського існування» [11, с. 460]. В 
епосі Гомера, говорить Г. Гегель, є все те, як давні греки уявляли собі світ, форму землі та океанів, життя богів, їх діяльність і вплив на життя людини. Поміж світу богів і світу людей і відбувається все людське як таке - звичаї, характери і події, мирні та військові ситуації.

Зовсім інше Г. Гегель знаходив у романі, у якому, з одного боку, виступає «в усій повноті багатство та багатогранність інтересів, станів, характерів, життєвих умов, широкий фон цілісного світу, а також епічне зображення подій» [11, с. 476], а 3 іншого, - у романі відсутній від початку поетичний стан світу, притаманний епосу. Тому він вважає, що роман передбачає вже «прозаїчно впорядковану дійсність» [Там само]. Звідси логічно виникає визначення колізії роману - «конфлікт між поезією серця та конфронтуючою 3 нею прозою життєвих стосунків, а також випадковістю зовнішніх обставин» [Там само].

Дослідження роману продовжилося у працях німецьких романтиків. Основою романтичної теорії роману стали філософські та естетичні побудови видатного німецького філософа Ф. Шеллінга, який започаткував оригінальну теорію роману. Він вважав роман таким родом літератури, у якому «окремий або обмежений матеріал стає предметом загальнозначущого i нібито байдужого зображення» [27, с. 170], тобто «приватною міфологією». Німецький філософ зіставляє роман і епос: «Уже те явне обмеження, що роман завдяки формі зображення є об'єктивним, загальнозначущим, указує, у яких межах він тільки й може приблизитися до епосу» [27, с. 171].

Але епос за своєю природою не обмежений, а роман обмежений предметом зображення, звідси випливає висновок про те, що роман наближується до драми, яка $є$ «обмеженою і замкненою в собі дією» [Там само]. Тому роман вбачається Ф. Шеллінгу змішаним родом, який поєднує ознаки епосу і драми. Вважаючи роман формою показу дійсності і героя, Ф. Шелліг підкреслює, що єдиним способом ставлення поета до героя повинна стати іронія, завдяки якій автор відокремлюється від свого героя і все суб'єктивне стає об'єктивною формою показу. Розглядаючи роман як форму, якій усе підвладне, Ф. Шеллінг вважав, що у романі $є$ все: і найвищий трагізм, і комізм, і показ будь-яких людських пристрастей. «Усе, що звичаї дають романтичного, - вважав він, повинно бути взяте, і не слід оминати авантюрне, якщо останнє знову ж таки буде придатне для символіки» [27, с. 172].

Головною колізією роману Ф. Шеллінг вважає відображення боротьби ідеального і реального: «ідеальне начало героя зіштовхується 
лише з буденним світом і буденними діями останнього» [Там само].

3 укріпленням позицій романтизму традиційні норми класицизму поступово витискуються 3 літературної теорії та художньої практики наприкінці XVIII - початку XIX ст. Романтизм зруйнував нормативність жанрів класицизму «і на перше місце висунув роман, своєрідний «антижанр», який ліквідовує звичні жанрові вимоги» [1, с. 33].

Романтики віддали данину вивченню роману та розробці його теорії, спираючись на програму романтичного мистецтва, яку вони проголосили. Романтична поезія, стверджували вони, не може бути вичерпана ніякою теорією, вона - поезія - «вільна й безкінечна», звідси й «сваволя поета», творча воля якого не може бути обмежена ніякими формальними нормами. Поет - творець форми, для нього не писані ніякі закони, він сам їх творець, наполягали романтики й розуміли категорію «жанр» широко.

Короткі нариси до теорії роману ми знаходимо в працях Ф. Шлегеля - одного 3 найяскравіших представників німецького романтизму. Наприкінці 1790-х р. брати Шлегелі видавали журнал «Атенеум» в якому були надруковані «Фрагменти» (1798), які складали в формі окремих нотаток і афоризмів теорію романтичної поезіі. Тут Ф. Шлегель дає визначення роману: «Романи - це сократівські діалоги нашого часу. Це вільна форма слугує притулком життєвої мудрості, яка рятується від шкільної мудрості» ) [30, с. 254].

Сократівські діалоги - жанр, що склався в епоху античності й зберіг форму тих діалогів, які вів Сократ зі своїми учнями. Важливою ознакою цього давнього жанру було те, що в ньому не формулювалася істина в іiі завершеному вигляді «шкільної мудрості», а були іiі пошуки, виражені у формі вільного діалогу учня й учителя. У «Розмові про поезію» Ф. Шлегель продовжує розмірковувати про природу роману. Він порівнює давню й нову поезію і підкреслює, що перша «цілком приєднується до міфології і навіть уникає дійсних історичних сюжетів», тоді як романтична поезія «цілком грунтується я на історичній основі», причому «набагато більшою мірою, ніж про це знають» [30, с. 255].

Важливою ознакою поезії нового часу, або романтичної, Ф. Шлегель вважає те, що вона побудована на дійсній історії, у якій і знаходить свої витоки романтичний вимисел; він підкреслював: істинну романтичну поезію не можна ототожнювати 3 сучасною поезією; наголошував, що для нього Шекспір і Сервантес більше романтики, ніж дехто із сучасних йому поетів. I тому для Ф. Шлегеля роман - той самий 
виток, у якому бере своє начало романтична поезія, подібно до того, «як поезія греків почалася з епосу» [Там само]. Він зауважував: «Роман - це первісна, самобутня, досконала форма романтичної поезії, яка відрізняється від давньої, класичної, де жанри строго розділені, саме цим змішанням усіх форм. Це абсолютно романтична, багато й майстерно сплетена композиція, де всілякі стилі різноманітно змінюють один одного; із цих різних стилів часто розвиваються нові твори, часто трапляється пародія» [31, с. 295]; «роман - це твір творів, ціле сплетіння поетичних утворень» $[31$, с. 99,100$]$.

Виходячи зі сказаного, можна зробити висновок про те, що для романтика Ф. Шлегеля роман являє собою те ж, що для грека епос. Роман, згідно з його позицією, стає синонімом романтичної поезії.

Так формувалися уявлення про роман у європейській літературі. Романна форма залишилася в полі зору теоретиків та істориків літератури Західної Свропи впродовж XVIII-XIX ст., і сама проблема походження та сутності роману не є суто пізнавальною, вона мала живе практичне значення.

Формування i розвиток роману в російській літературі спиралося перш за все на загальні історичні закономірності розвитку жанру в західно-європейській літературі Нового часу.

Роман з'являється в російській літературі в середині XVIII ст., і його подальший складний і суперечний розвиток повинен, на наш погляд, розглядатися тільки у зв'язку 3 загальним розвитком російської оповідальної прози. Виникнувши в 60-70-ті р. XVIII ст., російський роман не відразу досяг тих художніх форм, які пізніше стали його характерними ознаками.

Другу половину XVIII і початок XIX ст. можна розглядати як період накопичення сил. Як і спадщина оповідальних жанрів Давньої Русі, так і творчість письменників XVIII ст. - М. Чулкова, О. Ізмайлова, В. Нарєжного, які окреслили у своїй творчості основні теми, характерні образи та ситуації, мали для становлення російського роману вирішальне значення.

Найбільш поширеним жанром російської прози 1800-х p. залишається «романичний рід» (О. Галич), що виник ще у XVIII ст., і перш за все сентиментальна i романтична повість, яка інколи наближається до жанрових обрисів роману. Однак і цей рід зазнавав під впливом повістей М. Карамзіна суттєві зміни порівняно 3 повістями i романами XVIII ст. Російська повість і утворений відповідно до західних зразків роман були жанрами спорідненими. 
Спеціальні дослідження показують, що така ситуація характерна для російської літератури кінця XVIII - початку XIX ст. [20].

Традиції російського роману, закладені у XVIII ст., до початку XIX століття установилися й зміцніли, i роман, нарешті, стає найбільш повним і всебічним відображенням історичної долі російського народу та суспільства. Однак слід мати на увазі, що оригінальний російський роман не міг би виникнути й успішно розвиватися в XIX ст., якби розвиток давньоруської літератури не підготував для нього підгрунтя та низки теоретичних засад, які зробили форму роману історично закономірною та необхідною для подальшого розвитку російської літератури.

Перший етап у становленні класичного російського роману відзначений появою трьох шедеврів, які не тільки мали переломне, важливе значення в історії російської літератури, але й відразу ж піднесли російський роман на одне із перших місць у європейській літературі. Це - «Свгеній Онєгін», «Герой нашого часу» $\mathrm{i}$ «Мертві душі». Починаючи 3 40-х років XIX ст. у романах I. Тургенєва, О. Гончарова, О. Герцена, М. Лєскова, М. Щедрина, Ф. Достоєвського не тільки знайшли відображення всі різноманітні й складні проблеми російського життя, але й склалася поетика російського класичного роману в усій його своєрідності: від О. Пушкіна до Л. Толстого.

Вивчення теорії та історії російського роману завжди було в центрі уваги вітчизняної науки про літературу. Одне 3 перших визначень роману дав О. Пушкін. Він писав: «В наш час під словом роман мається на увазі історична епоха, яка була розвинута у вигаданому оповіданні» [18, с. 102].

У 1830-ті роки роман попадає в поле зору В. Бєлінського, який звертає на нього увагу вже в перших літературно-критичних виступах. Роман продовжує викликати зацікавлення письменника до кінця його літературно-критичної діяльності, причому, зауважимо, його погляди на сутність роману не залишалися незмінними: вони модифікувалися у зв'язку з загальною еволюцією світогляду критика.

В. Бєлінський абсолютно чітко вказує, що для роману необхідна приватна людина, значення якої античність ще не усвідомила; роману потрібна людина та його «вільна воля», суєта і дріб'язковість життя.

Для зображення життя героїв та богів, розмірковує далі критик, у Греції була поема, але «дитинство давнього світу закінчилося», і народилася ідея людини, «істоти індивідуальної» [6, с. 263]. 3 появою приватної 
«індивідуальної» людини народжується роман. Так з'являється лицарський «мрійливий» роман, який В. Бєлінський характеризує як суміш «бувалого й небувалого». Тільки у творчості Сервантеса та У. Шекспіра, на його думку, знову відбувається поєднання поезії 3 «дійсним життям».

Подальший розвиток роман, 3 позиції критика, отримав у творчості «нового великого генія» - В. Скотта. Становлення роману 3 часів Середньовіччя В. Бєлінський пов'язував із тим, що саме роман відображав життя прозаїчне, життя, яке воно є.

У статті «Розподіл поезії на роди та види» критик знову зупиняється на розпізнанні роману від епопеї, яке полягає в тому, що зміст роману - людина та іï приватне життя,точніше «саме життя в людині», тобто в герої роману.

Думка В. Бєлінського про зближення роману з життям залишиться найважливішою в переконаннях критика, який боровся в цей час за утвердження в російській літературі принципу реалізму. Вона залишиться важливою і при визначенні сутності самого жанру аж до XX ст., коли К. Тіандер писав: «Підйом роману співпадає 3 підйомом реалізму. Це наштовхує нас на думу, що роман і реалізм так тісно пов'язані один 3 одним, що реалізм є тим специфічним художнім змістом, який підходить до роману і тільки до роману, без якого роман те, що драма без дії та лірика без настрою» [22, с. 255-256].

В одній $з$ останніх своїх статей «Погляд на російську літературу 1847 року» В. Бєлінський знов звертається до питання про значення роману в російській літературі. Причина того, що роман став «головним серед інших родів поезіі», полягає «у самій сутності роману». По-перше, у романі сама неймовірна вигадка може зливатися 3 зображенням звичайної і навіть вульгарної прози життя, при цьому зображення цього «вульгарного життя» можуть представляти зразки «вищої творчості». По-друге, це самий «широкий, всеохоплюючий рід поезії; в ньому талант почуває себе безмежно вільним» [4, с. 315].

У своїх статтях, рецензіях і нотатках, у яких В. Бєлінський торкався історії не тільки російського але й європейського роману, він простежив зміну різних типів роману впродовж всієї історії розвитку цього жанру, починаючи з рицарського середньовічного роману і аж до роману XIX ст.

Слід підкреслити, що Л. Толстой головним у романі вважав не відображення будь-яких історичних подій, а відображення самої людини з іï пошуками щастя та добра, істини та доброчесності, тобто всіх тих вічних істин, які і складають його сутність.

() М. О. Дудніков, 2012. 
Роман, на думку Л. Толстого, жанр - надзвичайно «умовний» стає тією формою, у яку можна втілити будь-який зміст. Слід уважно поставитися й до іншого твердження письменника - про істотну різницю між романами європейського типу та російськими. Чи можна вибудувати пряму лінію розвитку від античного роману до роману російського питання, яке потребує відповіді. І відповідав - ні. До речі, М. Бахтін на це питання давав ствердну відповідь: «Так, можна», більше того, він вибудував лінію розвитку роману від античності до Достоєвського, поклавши в ії основу «пам'ять жанру».

Прагнення осмислити національну своєрідність російського роману нерідко приводило дослідників тих років до намагання протиставити його західноєвропейському. Один із перших істориків російського роману на Заході М. Вогюе у книзі «Російський роман» (1883-1886) намагався розглядати російський роман як таку форму, в основі якої лежать якісь метафізичні риси «слов'янської душі».

У другій половині XIX ст. на перше місце висувається російський роман, який став однією з вершин жанру.

До 1880-х років аналіз історичних і теоретичних проблем роману став поступово зникати зі сторінок літературних журналів і альманахів, тобто з поля зору російської літературної критики. У цей період роман починає привертати увагу академічної науки, і одним із перших видатних російських учених, який звернувся до його вивчення в руслі загальних проблем теорії та історії цього жанру, був Ф. Буслаєв.

У статті 1877 року «Значення роману в наш час» Ф. Буслаєв аналізуе причини стрімкого розвитку роману i його надзвичайної жанрової гнучкості. У зв'язку з цим він висловив думку про те, що роман, який став «панівним родом белетристики нашого часу», важко укладається в традиційну класифікацію літературних жанрів. Він обіймає різні види літературних творів і тому «оцінювати роман тільки 3 позиції епосу, лірики або драми - означало б далеко не вичерпати його багатого змісту і його складних завдань та ідей» [8, с. 411]. Ф. Буслаєв підтримував думку про роман як змішаний рід літератури, але розглянув тільки російський роман XIX ст.

Проблема вивчення роману перебувала в центрі наукових інтересів одного з найвідоміших вітчизняних учених - О. Веселовського. У 1876 році була опублікована стаття «Грецький роман», пізніше стаття «Рабле $\mathrm{i}$ його роман». У своєму університетському курсі «Теорія поетичних родів y ïx історичному розвитку» Веселовський значне місце відводить 
роману. У 1886-1888 роках учений випустив два томи досліджень під назвою «Із історії роману і повісті». Найбільш докладно загальні погляди О. Веселовського на розвиток роману викладені ним у статті 1886 р. «Історія чи теорія роману?», у якій він відштовхується від поглядів німецького дослідника роману Ф. Шпільгагена і його книги 3 теорії та техніки роману («Beitrage zur Theorie und Technik des Romans», 1883). Історія поетичного роду, - пише він у цій статті, - краща перевірка його теорії [9, с. 26]. Ця думка О. Веселовського покладена М. Бахтіним в основу всіх його досліджень про роман.

Походження епосу, лірики та драми трактувалося О. Веселовським як послідовне виділення трьох родів поезії 3 первинного синкретизму паралельно 3 «груповою» диференціацією та емансипацією особистості, з перетворенням заспівувача хору в співця i поета. Він, як і всі дослідники, які вивчали роман, починає з зіставлення роману з епосом. Для нього роман і епос - точки цілком віддалені дна від одної у процесі історичного розвиту. Героїчний епос виникає тоді, коли сам герой і співак ще не виокремлюються із народного цілого, тоді як роман втілює вершину розвитку особистісного начала в літературі. Автор у романі - це вже навіть не епічний співець, а утворювач реальності, представленої в романі. Автор - утілення суб'єктивного начала, якому відповідає і вимисел (або «вигаданість») любовної и авантюрної лінії роману. Для роману показовим $\epsilon$, наголошував О. Веселовський, інтерес до приватного життя людини. Учений так визначив шлях до роману: від епічного («об’єктивного») до особистого епосу («суб'єктивного»), від епічного співця до автора. Зіставляючи епічного співця і те, про що й для кого він співав, з автором роману, він підкреслює особливості цього жанру. Епічного співця відрізняло усвідомлення того, що він співає «лише про те, що бажає публіка, про що ніколи не втомлюється слухати» [9, с. 12].

Цікаві спостереження 3 історії та теорії роман, на наш погляд, містить праця К. Тиандера «Морфологія роману» [22, с. 175-256]. Ми не будемо ретельно зупинятися на аналізі основних положень цієї роботи, однак зазначимо, що К. Тиандер начало роману відносить «до перших століть нашого літочислення» і вважає, що він «є плодом елліністичної культури» [22, с. 176].

На його думку, роман виникає тоді, коли «Олександр Македонський розгромив давню Елладу i дав поштовх новим утворюванням через злиття східного і грецького елементів». Зі сходу () М. О. Дудніков, 2012. 
прийшли фантастичні казки, мальовничі описи пригод, які, поєднавшись 3 античною перебільшеною увагою до еротики, і дали, на думку К. Тиандера, рід оповідань, названий в майбутньому романом. Далі автор «Морфології роману» наводить схему побудови сюжетів найперших грецьких романів, де є втеча закоханої пари і пригоди, пов'язані з нею, випробування на вірність і як результат - шлюб. Цікаво, що ця ж схема роману майже так само повторена і М. Бахтіним при описі сюжетів грецьких романів.

Ще одне зауваження К. Тиандера, пов'язане з грецьким періодом розвитку жанру, видається суттєво важливим для розвитку нашої теми. Воно стосується питання щодо пародіювання романів елліністичної доби. «Коли Лукіан, - пише К. Тиандер, - висміював ці романи в своїх «Істинних оповіданнях», які нагадують нам пригоди барона Мюнхаузена, ним, можливо, керувало теж почуття, яке примусило Сервантеса озброїтися проти рицарських романів» [22, с. 177-178].

Отже, для К. Теандера початок роману - античність, Середньовіччя вже опановує той матеріал, який вона дала. Однак дослідник підкреслює, що провести різницю між епосом і романом в епоху Середньовіччя складно, оскільки роман ще не набув своєї форми: існує у віршах і прозі, хитаючись між ними.

3 позицій культурно-історичної школи підійшов до розгляду теоретико-літературних проблем роману В. Сиповський. У 1909 р. 3'являються його «Нариси історії російського роману». Важливим аспектом роботи слід вважати спробу систематизувати російський роман з опертям на західно-європейський досвід та історію розвитку європейського роману. Учений вважав, що найбільше вплинули на розвиток російського роману - «Жілблаз», «Нова Елоїза» i «Страждання молодого Вертера». За цими творами слідувала низка інших західно-європейських романів, розроблених за тими ж шаблонами, які вперше були введені в літературний обіг як новації. Очевидно, що російський роман, на думку вченого, розвивається згідно 3 тими ж законами, які наслідували західно-европейські романи.

В. Сиповський розподіляє європейські романи на три типи. Перший тип - роман псевдо-класичний (А) 3 позитивним героєм: а) «роман придворний героїчно-галантного типу» - Кальпренед, Скюдері i, як розвиток його, Лафайєт; б) політичний роман - тип «Телемака»; в) - тип роману Прево. Інша група романів (Б) з негативним героєм - 
тип «Жілблаза». Розподіл за типом героя вважається дослідникові більш точним, оскільки термінологічна неясність («ідеалістичний») або («реалістичний») заважає точній класифікції.

Друга група романів - чарівний рицарський роман розподіляється на три підгрупи. Це «рицарський роман-поема» (Аріосто, Баядеро та ін.); східні казки» (тип «Казок 1001 ночі); «казки про фей» (у своєму розвитку вони доходять до Ж. Мармонтеля та ін.).

Третя група романів - англійський психологічний сімейний роман, який розпадається на три підгрупи: роман на зразок творів Річардсона, роман на зразок «Нової Елоїзи», роман на зразок «Страждання молодого Вертера». Усі ці типи певним чином вплинули на становлення російського роману.

Праці В. Сиповського завершують дослідження російської академічної літературознавчої школи в галузі вивчення історії та теорії роману. У 1910-ті р. розпочинає свою діяльність ОПОЯЗ.

Для розуміння розвитку теорії та історії роману досить цікавим $\epsilon$ досвід російської формальної школи, у полеміці 3 основними положеннями якої уточнювалася історико-літературна і теоретична концепція М. Бахтіна. Як відомо, у російських формалістів було багато як прибічників, так і опонентів, до яких входив М. Бахтін. Численні його праці 1920-х р. складалися в полемічній суперечцідіалозі 3 відомими представниками російського формалізму, передусім - В. Шкловським, В. Жирмунським, Б. Ейхенбаумом.

У полемічно-загострених виступах М. Бахтіна проти основних положень, які висували формалісти, слід указати й на його заперечення, що стосуються теорії роману.

Авторитет і вплив поступово перейшли від академічної науки до науки, так би мовити, журнальної - до критиків і теоретиків символізму. «Дійсно, з 1907 по 1912 рр. набагато більший вплив мали книги та статті Вяч. Іванова, В. Брюсова, А. Белого, Д. Мережковського, К. Чуковського та інших, а не дослідження і дисертації університетських професорів» [33, с. 119].

Сильною стороною формалізму було, безперечно, те, що він звернув увагу на розв'язання найважливіших проблем теорії літератури і теорії жанрів зокрема. Не вдаючись у детальний розгляд основних теоретичних положень ОПОЯЗу, можна висловити їх відомою формулою: художній твір $\epsilon$ сумою прийомів. Прийом перетворює неестетичний матеріал у витвір мистецтва. Невипадково 
ранні формалісти часто послуговувалися словом «зроблено», або «твір зроблений». Таке формулювання широко використовується в науковому термінологічному апараті ОПОяЗу. У вірші, новелі, романі формалізм насамперед знаходив композиційну основу, питання про смислову побудову майже не ставилося.

Середина 1920 - початок 1930-х р. стали переломними у становленні бахтинської концепції роману. У цей період М. Бахтін написав роботу «Проблема змісту, матеріалу і фоми в словесній художній творчості» (1924), у якій звернувся до розробки проблем поетики літературного твору.

Полеміка М. Бахтіна 3 формальною школою - початок формування ключових аспектів його власного розуміння роману: «Для того, щоб відтворити роман, потрібно навчитися бачити життя так, щоб воно могло стати фабулою роману, необхідно вчитися бачити нові, більш глибокі і більш широкі ходи життя...», тому «логіка романної конструкції дає змогу оволодіти своєрідною логікою нових сторін дійсності» [16, с. 255].

Звернемося також до робіт В. Шкловського, Б. Ейхенбаума, Ю. Тинянова, у яких вони висловлювалися щодо романного жанру. Проблема роману розглядалася В. Шкловським у багатьох його статтях та дослідженнях різних років, зокрема і в 1950-ті [29].

Дослідник починає аналіз одного 3 перших зразків європейського роману - роману грецького. Учений зауважував, що застосовувати термін «грецький роман» до оповідань античності слід обережно, щоб «разом із терміном не перенести більш пізнє уявлення на ранні явища» [29, с. 140]. Грецький роман, вважав В. Шкловський, був відтворений містом, «старим, замкненим містом, у якому всі знають не лише сусідів, але й усіх їх предків...» Крім того, розпад античного світу, труднощі та страхи, пов’язані з відкриттям нового «величезного всесвіту, просторих океанів, невідомих народів, чужих звичаїв, були реальністю грецьких романів» [29, с. 149].

Лицарські романи, на його думку, були надзвичайно поширені, ïx знали навіть люди неграмотні. Роман же нового часу 3'являється після Сервантеса. У «Дон Кіхота» було не тільки велике й славне життя, але головна заслуга роману полягає в тому, що Сервантес зміг абсолютно чітко подати наступним поколінням поетику роману рицарського. Роман Сервантеса довгий час залишався зразком для наступних романістів, зокрема для Г. Філдінга. «Роман нового типу, - 
пише вчений, - роман про долю героя, освітлений його психологією, переміг, хоч і не відразу» [29, с. 233]. В. Шкловський розглянув багато категорій поетики роману, звернув увагу на те, що великі епохи в історії літератури - «одночасно епохи теоретичні; епохи Сервантеса, Філдінга, Стерна утримують у собі нові теорії романів» [29, с. 308].

Для розуміння місця і значення роману в теоретичних пошуках формалістів важливі роботи Ю. Тинянова 1920-х р., коли виникає інтерес до проблеми жанру, а також і роману. Дослідник розглянув низку проблем жанру роману на прикладі пушкінського «Свгенія Онегіна». Смисл поезії відрізняється від смислу прози, підкреслював учений, і тому, коли у прозу (наприклад, роман) упроваджений вірш, то семантичні елементи роману в цьому разі деформуються віршем. Потужною семантичною одиницею роману Ю. Тинянов вважав його героя, а у віршованому романі герой міняється частіше, бо змінюються самі елементи роману. «Тому герой віршованого роману не $\epsilon$ герой того ж роману, перекладеного у прозу» [25, с. 56].

Особливе місце займає стаття Б. Ейхенбаума «Як зроблена «Шинель» Гоголя». На матеріалі прози Гоголя іiі автор розглянув питання стосовно того, яку роль у композиції новели або повісті відіграє особистий тон автора. Стаття гостро полемічна. В. Шкловський про неї писав, що вона «прямолінійно блискуча: вона й через півстоліття викликає суперечки. Вона визначила дуже багато в майбутньому аналізі прози» [28, с. 21].

Б. Ейхенбаум аналізує слово. «Звукова оболонка слова, його акустична характеристика, - пише він, - стає в мові Гоголя значущою незалежно від логічного або матеріального значення. Артикуляція та іiі акустичний ефект висуваються на передній план як виразний прийом» [33, с. 48]. Говорячи про концепцію роману, слід звернути увагу на огляд німецької літературної науки, яка значно вплинула на російську на початку XX ст. Наприклад, В. Виноградов так характеризував цей процес: «Наша вітчизняна концепція поетики розвивалася паралельно 3 концепціями західноєвропейського типу - шкіл К. Флоссера, Л. Шпитцера, О. Вальцеля та ін. - і самостійно від них, хоч іноді й зважала на їх результати» [10, с. 176].

На початку XX ст. серед досліджень про роман вагоме місце займає концепція роману Г. Лукача, викладена у книзі «Теорія роману», яка вийшла в світ у Берліні в 1920 р. У 1963 р. було здійснене друге () М. О. Дудніков, 2012. 
видання 3 передмовою автора [34]. Філософсько-методологічна своєрідність книги Г. Лукача полягає в тому, що іï автор нібито рухається від Канта до Гегеля. «Пошуки єдності та цілісності світу, пізнання субстанційних основ буття в Г. Лукача - проблема романного мистецтва, а конфлікт героя зі світом - засіб ії розробки» [19, с. 69].

Ця концепція Г. Лукача наближена до розуміння роману Гегелем. «Теорія роману»- це не єдина робота Г. Лукача, у якій досліджуються проблеми роману. Не менш цікавою є його праця «До історії реалізму». Тут цілу низку розділів присвячено розгляду романної творчості І. Гете, О. де Бальзака, Ф. Стендаля, Л. Толстого [15]. I в цій розвідці Г. Лукач загалом розвиває думки Гегеля, розглядаючи античний епос як втілення гармонії людини та світу, де сенсом життя $є$ саме життя. Роман - епос обезбоженого світу, і для Г. Лукача «форма роману $<\ldots>\epsilon$ вираженням трансцендентальної бездомності» людини, на відміну від епопеї, яка виражає цілісність життя» [34, с. 57-58].

Г. Лукач дійшов висновку: роман - продукт розпаду і деградації епічної цілісності. Мистецтво роману - повернення втраченої цілісності, що, з позиції вченого-марксиста, може відбутися тільки в мистецтві соціалістичному, тому він і робить узагальнення про необхідність установлення нормативного жанру - роману-епопеї як еталонного жанру.

Роман у Г. Лукача - та форма, яка змінила епос. Завдання подальшого розвитку літературних форм полягає в подоланні роману як такого і повернення до епопеї, звідси в дослідника й вимоги нормативного характеру: у літературу повинна повернутися і стати основною форма роману-епопеї. Учений доходить до заперечення роману як літературної форми взагалі. Відтворюючи своєрідну «нормативну теорію» роману, М. Римарь справедливо підкреслює, що він вступає в суперечність 3 художньою практикою самого жанру.

Розгляд роману в історичній опозиції «епос - роман» давно прийнятий в історії вивчення жанру. М. Бахтін кваліфікує епос і роман як різні естетичні субстанції, які до того ж мають і різну естетичну дистанцію («ціннісно-часову»). Однак, на відміну від Г. Лукача, він розглядає їх не як гарний або поганий («цілісний» $\mathrm{i}$ «автоматизований»), а як субстанції рівновеликі. Через епос роман характеризується об'ємно і дає змогу найбільш повно показати особливості побудови образу: романний герой не дорівнює самому собі, здатний змінюватися, тобто повернений у майбутнє. У статті 
італійського русиста В. Стради «Між романом і реальністю. Історія критичної рефлексії» порівнюються погляди на роман Г. Лукача та М. Бахтіна. Розбіжності спостерігаються в тому, як дослідники визначають місце та значення епосу: «для Лукача роман відзначений негативним знаком, оскільки $\epsilon$ «вираженням втрати» епічної цілісності, а для М. Бахтіна втрата епічного світу означає набуття нової форми - форми роману, отже, відзначений позитивним знаком, бо роман відкриває епоху вільного плюралізму, міжособистісної діалогічності, радості деірархізації» [21, с. 37-38].

Слід звернути увагу на книгу Б. Грифцова «Теорія роману» (1927). У ній вчений намагається пояснити логіку романного вимислу. Він виходив із того, що за цілі століття існування роману слово «романний» стало синонімом дивного та чудового, тобто того, що подане в описах романних подій. «Як би не старалися історики літератури довести, що все більше й більше реалістичним стає роман, - писав він, - звичайний читач під «романом» перш за все має на увазі «вигадку», «вимисел», особливе, цікаве, зумовлене завданням знайти вихід зі складних обставин» [12, с. 17]. Ці висловлювання свідчать про модифікаційну тенденцію романного жанру. А вимисли та ретроспективні уявлення, які відбиваються в сюжетах художніх творів $\epsilon$ свідченням формування поетики романів на історичну тематику. Стаття матиме логічне продовження в контексті еволюційних процесів роману на сучасному етапі.

\section{Література}

1. Аверинцев С. С. Категории поэтики в смене литературных эпох / С. С. Аверинцев, М. Л. Андреев, М. Л. Гаспаров // Историческая поэтика. Литературные эпохи и типы художественного сознания. - М. : Наследие, 1994. - С. 3-38.

2. Античный роман. Ахилл Татий Александрийский. Левкиппа и Клитофонт / Под ред. Богаевского с вступ. ст. Болдырева. - М. : Государственное изд-во, 1925. - 192 с.

3. Бахтин М. М. Вопросы литературы и эстетики. Исследования разных лет / М. М. Бахтин. - М. : Художественная литература, 1975. - 504 c.

4. Белинский В. Г. Взгляд на русскую литературу 1847 года / В. Г. Белинский // Полн. собр. соч. - М. : Изд-во АН СССР, 1956. - Т. 10. -453 с.

5. Белинский В. Г. Объяснение на объяснение по поводу поэмы Гоголя «Мертвые души» / В. Г. Белинский // Полн. собр. соч. : в 13-и т. - М. : Изд-во АН СССР, 1953. - Т.1.-572 с.

6. Белинский В. Г. О русской повести и повестях г. Гоголя / В. Г. Белинский // Полн. собр. соч. - М. : Правда, 1953. - Т.1.- 572 с.

7. Болдырев А. В. Художественная повествовательная проза І-Ш вв. н. э. / А. В. Болдырев // История греческой литературы : в 3-х т. - М. : Наука, 1960. - С. 241-272.

8. Буслаев Ф. И. Мои досуги : в 2-х ч. / Ф. И. Буслаев. - М., 1886. - Ч. 2. - С. 410-417. 
9. Веселовский А. Н. История или теория романа? / А. Н. Веселовский // Из истории романа и повести. - Вып.1. - СПб., 1886. - С. 3-29.

10. Виноградов В. В. Стилистика. Теория поэтической речи. Поэтика / В. В. Виноградов. - М. : Наука, 1963. - 530 с.

11. Гегель Г. Эстетика : в 4-х т. / Г. Гегель. - М. : Искусство, 1971. - Т. 3.- 621 с.

12. Грифцов Б. А. Теория романа / Б. А. Грифцов. - М. : Типография «Мосполиграф», 1927. $-151 \mathrm{c}$.

13. Кожинов В. В. Происхождение романа / В. В. Кожинов. - М. : Советский писатель, 1963. - 439 с.

14. Кожинов В. В. Эстетическая ценность романа / В. В. Кожинов // Русская и зарубежная литература. Исследования, статьи, публикации. - Учен. зап. - Вып. 61. Саранск, 1967. - С. 25-43.

15. Лукач Г. К истории реализма / Г. Лукач. - М. : Гослитиздат, 1939. - 372 с.

16. Медведев П. Н. Формалный метод в литературоведении. Критическое введение в социологическую поэтику / П. Н. Медведев // М. М. Бахтин. Тетралогия. М. : Лабиринт, 1998. - 607 с.

17. Михайлов А. В. Роман и стиль / А. В. Михайлов // Теория литературных стилей. Современные аспекты изучения. - М., 1982. - С. 137-203.

18. Пушкин А. С. Юрий Милославский, или Русские в 1612 году / А. С. Пушкин // Полн. собр. соч. - М. : Наука, 1964. - Т. 7. - 997 с.

19. Рымарь Н. Т. Введение в теорию романа / Н. Т. Рымарь. - Воронеж : Изд-во ВГУ, 1989. - 270 с.

20. Сиповский В. В. Из истории русского романа и повести. XVIII век / В. В. Сиповский. - СПб. : Паровая скоропечатная Г. П. Пожарова, 1903. - Ч. 1. 1903. - $351 \mathrm{c}$.

21. Страда В. Между романом и реальностью. История критической рефлексии / В. Страда // Бахтинский сборник. - Вып. 5. - М., 2004. - С. 22-40.

22. Тиандер К. Ф. Морфология романа / К. Ф. Тиандер // Вопросы теории и психологии творчества : в 2-х т. - М., 1909. - Вып. 1. - Т. 2. - С. 255-256.

23. Толстой Л. Н. Несколько слов по поводу книги «Война и мир» / Л. Н. Толстой // Полн. собр. соч.: в 90-т. - М. : Гос. изд-во худож. лит., 1955. - Т. 16. -256 с.

24. Толстой Л. Н. Полн. собр. соч.: в 90-т. / Л. Н. Толстой. - М. : Гос. изд-во худож. лит., 1955. - Т. 13. - 253 с.

25. Тынянов Ю. Н. Поэтика. История литературы. Кино / Ю. Н. Тынянов. - М. : Наука, 1977. - 574.

26. Филдинг Г. История Тома Джонса, найденыша : в 2-х т. / Г. Филдинг. - М. : Политиздат, 1960. - 294 с.

27. Шеллинг Ф. Философия искусства / Ф. Шеллинг // История эстетики : в 5-и т. - М. : Наука, 1967. - Т. 3. - 405 с.

28. Шкловский В. Б. Тетива. О несходстве сходного / В. Б. Шкловский. - М. : Советский писатель, 1970. - 375 с.

29. Шкловский В. Б. Художественная проза. Размышления и разборы / В. Б. Шкловский. - М. : Советский писатель, 1959. - 627 с.

30. Шлегель Ф. Фрагменты / Ф. Шлегель // История эстетики : в 5-и т. / Ф. Шеллинг. - М. : Наука, 1967. - Т. 3. - 405 с.

31. Шлегель Ф. Эстетика. Философия. Критика / Ф. Шлегель. - М. : Искусство, 1983. -479 c. 
32. Эйхенбаум Б. М. Как сделана «Шинель» Гоголя / Б. М. Эйхенбаум // О прозе. О поэзии. - Л. : Худож. л-ра., 1986. -456 с.

33. Эйхенбаум Б. М. Теория «формального» метода / Б. М. Эйхенбаум // Литература. - Сб. Пг., 1926. - С. 119.

34. Lukacs G. Die Theorie des Romans / G. Lukacs. - Berlin-Spadau: Luchterhand, 1963. $-157 \mathrm{~s}$.

35. Williams I. Novel and Romance» / I. Williams. University of Tennessee, Knoxville. http://web.utk.edu...

Стаття надійшла до редакції 10.12.2012 p. 